\title{
GROWTH RESPONSE OF Bauhinia Variegata L. TO INOCULATION AND ORGANIC FERTILIZATION ${ }^{1}$
}

\author{
Caliane da Silva Braulio ${ }^{*}$ (), Rafaela Simão Abrahão Nóbrega ${ }^{3}$, Flávia Melo Moreira ${ }^{4}$ (i), Ângela \\ Santos de Jesus Cavalcante dos Anjos ${ }^{5}$ [D, Janildes de Jesus da Silva ${ }^{6}$ and Juan Manuel Anda \\ Rocabado $^{2}$ (1)
}

\footnotetext{
${ }^{1}$ Received on 06.04.2018 accepted for publication on 28.03.2019.

${ }^{2}$ Universidade Federal do Recôncavo da Bahia Programa de Pós-Graduação em Solos e Qualidade de Ecossistemas, Cruz das Almas, BA - Brasil. E-mail: <caliane.braulio@gmail.com> and <quirito2000@yahoo.com.br>.

${ }^{3}$ Universidade Federal do Recôncavo da Bahia, Centro de Ciências Agrárias, Cruz das Almas, BA - Brasil. E-mail: $<$ rafaela.nobrega@gmail.com>.

${ }^{4}$ Universidade Federal do Recôncavo da Bahia Programa de Pós-Graduação em Agronomia, Cruz das Almas, BA - Brasil. E-mail: <fmmoreira_ef@yahoo.com.br>.

${ }^{5}$ Universidade Federal do Recôncavo da Bahia Graduada em Agroecologia, Cruzdas Almas, BA-Brasil.E-mail: $<$ angelasjca@hotmail.com>. ${ }^{6}$ Universidade Federal do Recôncavo da Bahia, Cruz das Almas, BA - Brasil. E-mail: <janildesdejesus@hotmail.com>.

*Corresponding author.
}

\begin{abstract}
The objective of this work was to evaluate the initial growth of Bauhinia variegata L. when inoculated and fertilized with different proportions of organic compost. The experiment was performed in greenhouse in a completely random factorial $(2 \times 5)+1$ design, with 9 replicates, constituted by the presence or absence of inoculation, five proportions of organic compost:soil (0:100, 20:40,40:60, 60:40 and 80:20; v/v) and one additional treatment with chemical fertilization without inoculation. Ninety days after sowing, the plant height, stem diameter, number of leaves, radicular length, dry mass of the aerial portion, dry mass of roots, total dry mass, Dicksosn's quality index (IQD), contents of nitrogen and carbon and the $\mathrm{C} / \mathrm{N}$ ratio of the dry mass of the aerial portion, were evaluated. The inoculation with diazotrophic bacteria stimulated growth in height, stem height/diameter ratio, dry mass of the aerial portion, dry mass of roots, total dry mass and the foliar contents of nitrogen and carbon in seedlings of $B$. variegata L. Seedlings grown using organic compost showed better development when compared to seedlings grown only in soil with or without chemical fertilization. Seedlings grown with formulated substrate at a proportion of 16:84 (organic compost:soil + inoculation) exhibited higher IQD, therefore, this constitutes the recommended proportion for production of B. variegata L. seedlings.
\end{abstract}

Keywords: Plant growth promoting bacteria; Organic compost; Seedling production.

\section{CRESCIMENTO DE BAUHINIA VARIEGATA L. EM RESPOSTA A INOCULAÇÃO E FERTILIZAÇÃO ORGÂNICA.}

\begin{abstract}
RESUMO-Objetivou-se avaliar o crescimento inicial de Bauhinia variegata L. em função da inoculação e adubação com diferentes proporções de composto orgânico. O experimento foi conduzido em casa de vegetação, sendo disposto em delineamento experimental inteiramente casualizado em arranjo fatorial $(2 x 5)+1$, com 9 repetições, constituidos da presença e ausência de inoculante, cinco proporções de composto orgânico:solo (0:100, 20:40, 40:60, 60:40 e 80:20; v/v) e um tratamento adicional com adubação química sem inoculante. Após 90 dias da semeadura, avaliaram-se: a altura, o diâmetro do colo, o número de folhas, o comprimento radicular, a massa seca da parte aérea, da raiz e total, o índice de qualidade de Dickson (IQD), os teores de nitrogênio e carbono e a relação $C / N$ da massa seca da parte aérea. A inoculação de bactérias diazotróficas estimulou o crescimento em altura, a relação entre altura e diâmetro do caule, massa seca da parte aérea, raiz e total, e os teores de nitrogênio e carbono foliares das mudas de B. variegata L. Mudas cultivadas com composto orgânico apresentaram melhor desenvolvimento em relação às cultivadas em solo com e sem adubação química. As mudas cultivadas com o substrato formulado com a proporção de 16:84 (composto orgânico:solo + inoculação) apresentaram maior IQD, sendo, portanto, essa proporção recomendada para a produção de mudas de B. variegata $L$.
\end{abstract}

Palavras-Chave: Bactérias promotoras de crescimento vegetal; Composto orgânico; Produção de mudas. 


\section{INTRODUCTION}

Organic residues from agricultural or urban activities, after being processed by composting, render an organic material with desirable characteristics to produce substrates for seedling production. Positive results obtained by mixing residues are observed in arboreal species (Duarte and Nunes, 2012; Sousa et al., 2013; Cavalcante et al., 2016; Medeiros et al., 2017). In addition to a significant reduction of environmental pollution through an adequate destination of residues, the use of organic residues contributes for crop production enabling the recycling of residues (Rodrigues et al., 2011) and the reduction of expenses with plant production.

Thus, the use of residues produced in farms and originated from agricultural and urban activities, such as prune of trees, manure and food residues, may contribute to aggregate value to the agricultural activity, through their employment as conditioners or fertilizers in growth substrates.

In addition to the quality of the growth substrate, which depends on its nutrient availability (Delarmelina et al., 2014; Sousa et al., 2016; Krefta et al., 2017) and its physical attributes (Medeiros et al, 2017); the association or symbiosis between plants and bacteria may enhance the development of seedlings in the nursery (Ferreira et al., 2015; Freire et al., 2017; Porto et al., 2017) and in field conditions, when associated to organic substrates (Fernandes et al., 2017).

Bauhinia variegata L. is an exotic fast growing leguminous species, belonging to the family Fabaceae and commonly known as cow's hoof(Krefta et al., 2017). It is considered a medicinal plant, once it shows phytotherapeutic effects and contains phenolic compounds with anti-oxidant properties (Nascimento et al., 2011). This species is widely used for foresting and recovering of degraded land (Lorenzi, 2008). Previous studies showed that species form this genus have positive responses to organic fertilization (Duarte and Nunes, 2012; Fernandes et al., 2015). There are literature data registering the use of cow urine at $5 \%$ concentration influencing the growth of Bauhinia forficata (Raulino et al., 2015). However, there is no information regarding the nodulation of the genus Bauhinia, neither studies demonstrating the effects of growth promoting bacteria in $B$. variegata $\mathrm{L}$. The evaluation of easy available and alternative substrates, in conjunction with inoculation of growth promoting bacterial, is significant when aiming the production of quality seedlings in shorter periods in the nursery. In such context, the objective of this work was to evaluate the initial growth of $B$. variegata $\mathrm{L}$. when inoculated with growth promoting bacteria and fertilized with organic compost.

\section{MATERIALAND METHODS}

The experiment was performed in a nursery at the Agriculture, Environment and Biological Sciences Center form the Federal University of the Recôncavo da Bahia (UFRB), in the city of Cruz das Almas, state of Bahia, located at South latitude $12^{\circ} 40^{\prime} 19^{\prime \prime}$ and West longitude $39^{\circ} 06^{\prime} 23^{\prime \prime}$, set up under a completely random design with $(2 \times 5)+1$ factorial scheme and 9 replicates. The treatments were constituted by two dosages of inoculant (absence and presence of inoculant), five proportions of organic compost:soil (0:100, 20:40, 40:60, 60:40 and $80: 20)(\mathrm{v} / \mathrm{v})$, and one additional treatment with chemical fertilization without inoculation, with a total of 99 experimental units. The soil used in the substrates was a dystrophic Red Latosol collected at the UFRB Campus at a depth of $40 \mathrm{~cm}$. Organic compost was also produced at the UFRB, in a compost heap composed by pruned trees and cattle and goat manure, at a $3: 1: 1$ ratio.

Soil and organic compost were dried and sieved through a $4 \mathrm{~mm}$ mesh, homogenized and conditioned in plastic bags with $0,12 \times 0,23 \mathrm{~m}$ and volume of 1,2 $\mathrm{dm}^{-3}$. The additional treatment was constituted by 100 $\mathrm{mg} \mathrm{dm}{ }^{-3}$ of nitrogen (urea as source), $100 \mathrm{mg} \mathrm{dm}^{-3}$ of potassium (potassium chloride as the source) and 150 $\mathrm{mg} \mathrm{dm}^{-3}$ of phosphorus (simple superphosphate as source).

Chemical characterization of the soil and the compost was performed at the Soil Sciences laboratory from the University of São Paulo - ESALQ and was described as: $\mathrm{pH}\left(\mathrm{H}_{2} \mathrm{O}\right): 5.2 ; \mathrm{pH}\left(\mathrm{CaCl}_{2}\right): 4.5 ; \mathrm{P}: 11.2 \mathrm{mg} \mathrm{dm}^{-3} ; \mathrm{K}^{+}$: $74 \mathrm{mg} \mathrm{dm}{ }^{-3} ; \mathrm{Ca}^{2+}: 0.8 \mathrm{cmol}_{\mathrm{c}} \mathrm{dm}^{-3} ; \mathrm{Mg}^{2+}: 0.4 \mathrm{cmol}_{\mathrm{c}} \mathrm{dm}^{-3}$; $\mathrm{Al}^{3+}: 0.3 \mathrm{cmol}_{\mathrm{c}} \mathrm{dm}^{-3}$; Potential acidity: $2.6 \mathrm{cmol} \mathrm{dm}^{-3}$; Sum of bases: $1.4 \mathrm{cmol}_{\mathrm{c}} \mathrm{dm}^{-3}$; T: $4 \mathrm{cmol}_{\mathrm{c}} \mathrm{dm}^{-3}$; Basis saturation: $35 \%$; MO: $<14.4 \mathrm{~g} \mathrm{~kg}^{-1}$. Chemical attributes of the organic compost were described in humid basis: $\mathrm{pH}\left(\mathrm{H}_{2} \mathrm{O}\right): 7.0 ; \mathrm{pH}\left(\mathrm{CaCl}_{2} 0.01 \mathrm{M}\right): 6.4$; Density: 1.00 $\mathrm{g} \mathrm{cm}^{-3}$; Humidity at $60-65^{\circ} \mathrm{C}: 12.03$ (\%); Humidity at $110^{\circ} \mathrm{C}$ : 0.69\%; Organic Matter: $10.64 \%$; Organic Carbon: 5.27\%; Total Mineral Residue: 76.64\%; Mineral Residue: 5.76\%; Non-soluble Mineral Residue: $70.88 \%$; Total Nitrogen: $0.62 \%$; Total Phosphate: 0.20\%; Total

Revista Árvore. 2019;43(1):e430104

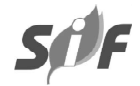


Potassium: $0.22 \%$; Total Calcium: $0.50 \%$; Total Magnesium: $0.11 \%$; Total sulfur: $0.02 \%$; $\mathrm{C} / \mathrm{N}$ ratio: 9; Copper: $13 \mathrm{mg} \mathrm{kg}^{-1}$; Manganese: $112 \mathrm{mg} \mathrm{kg}^{-1}$; Zinc: $31 \mathrm{mg} \mathrm{kg}^{-1}$; Boron: $206 \mathrm{mg} \mathrm{kg}^{-1}$; Sodium: $725 \mathrm{mg} \mathrm{kg}^{-1}$.

Seeds of $B$. variegata were collected and separated by size, obtaining a uniform batch from 15 matrices from the county of Cruz das Almas-BA, Brazil. Seeds were manually selected and disinfected in pure ethanol for 5 seconds and sodium hypochlorite $1 \%$ for 2 minutes, followed by successive washes in sterilized distilled water and finally submerged in ethylic alcohol for 15 minutes to overcome seed dormancy (Smiderle and Luz, 2010). Subsequently, seeds were inoculated with diazotrophic bacteria.

The inoculum was prepared in peat using a mixture of diazotrophic bacterial inocula authorized by the Ministry of Agriculture, Livestock and Supply (Brasil, 2011). The strains used were INPA $0311 \mathrm{~B}$ and UFLA 0384 (Lacerda et al., 2004), recommend for Vigna unguiculata, and the strain UFLA 03164 (still in evaluation stage). These strains were used to verify nodulation and/or growth promotion ability on $B$. variegata.

The bacteria were multiplied in semi-solid YMA medium, also denominated 79, incubated in BOD chamber for 6 days at $30^{\circ} \mathrm{C}$. The inoculum mixture was constituted by the addition of $3.0 \mathrm{~mL}$ of mediums containing the strains INPA 0311B, UFLA 0384 and UFLA 03164 with approximately $10^{8} \mathrm{UFC} \mathrm{mL}^{-1}$ each. Then, peat was added at a volume of three parts per part of inoculum. Finally, after inoculation, the sowing was performed with five seeds per bag at $2.0 \mathrm{~cm}$ depth. Thirty days after sowing, thinning was executed leaving only one plant per bag. Irrigation was performed daily according needed, aiming to simulate the conditions of commercial nurseries.

Ninety days after sowing, seedlings were evaluated for: height $(\mathrm{H})$, stem diameter (ST), number of leaves (NL), root length (RL) and number of nodules (NN). Seedlings were divided in two parts: aerial portion and roots; dried in a forced air drying oven at $65^{\circ} \mathrm{C}$ until a constant mass was verified. Then, parts were measured and the dry mass of the aerial portion (DMAP), dry mass of roots (DMR), total dry mass (TDM), ratio between stem high and stem diameter (H/DC) and the Dicksosn's quality index (IQD) (Dickson et al., 1960), were evaluated. The dry mass of the aerial portion was used to determine the contents of nitrogen $(\mathrm{N})$ and carbon $(\mathrm{C})$ by the method of dry combustion in an Elementar Vario El (LECO, EUA) analyzer, at the laboratory of Soil and Vegetal Tissue Analyses from Embrapa Semi-arid. The carbon/nitrogen ratio $(\mathrm{C} / \mathrm{N})$ was then determined.

Data was submitted to a variance and polynomial regression analyses, according to the proportions of organic compost and dosages of inoculant, using the statistical software SISVAR (Ferreira, 2014).

\section{RESULTS}

Nodules were not observed in the radicular system of Bauhina variegata L. seedlings cultivated in the evaluated substrates.

Interaction $(p<0.01)$ between the proportions of organic compost with and without inoculant was verified for the variable of plant height $(\mathrm{H})$, showing a quadratic behavior (Figure 1A). The organic compost stimulated growth (in height) of the seedlings, both in the presence and absence of the inoculant. With inoculation, a maximum $\mathrm{H}$ of $12.02 \mathrm{~cm}$ plant $\mathrm{t}^{-1}$ was observed in plants cultivated with substrate constituted of 29:71 (organic compost:soil). In the absence of inoculant the substrate constituted of 9:91 (organic compost:soil) resulted in a maximum of $11.07 \mathrm{~cm} \mathrm{plant}^{-1}$ (Figure 1A).

Seedling increase in $\mathrm{H}$ was enhanced with the use of organic compost:soil + inoculation up to $54.31 \%$, when compared to seedlings cultivated only in soil $(0: 100 \mathrm{v} / \mathrm{v})$. Seedlings cultivated in substrate with chemical fertilization (additional control) showed lower mean values $\left(10.86 \mathrm{~cm} \mathrm{plant}^{-1}\right)$ that the other treatments (Figure $1 \mathrm{~A})$. Regarding the stem diameter (SD), there was individual effect $(p<0.01)$ of the organic compost:soil proportions. The estimated proportion of 22:78 (organic compost:soil), resulted in maximum SD of $2.47 \mathrm{~mm}$ plant ${ }^{1}$, being $28.34 \%$ higher when compared to the substrate constituted only by soil (0:100 v/v) (Figure 1B). Seedlings cultivated in substrate with chemical fertilization showed lower SD (2.23 mm plant $\left.{ }^{-1}\right)$, when compared to organic compost (Figure 1B).

As regards to the number of leaves (NL) and root length (RL), there was individual effect $(p<0.01)$ of the organic compost proportions. The substrate elaborated with organic compost provided a maximum NL of 5.01 leaves plants ${ }^{-1}$, for an estimated proportion of 19:81 (organic compost:soil) with an increment of $59 \%$, when compared with the substrate constituted only by soil $(0: 100 \mathrm{v} / \mathrm{v})$ (Figure $2 \mathrm{~A})$. Chemical fertilization 

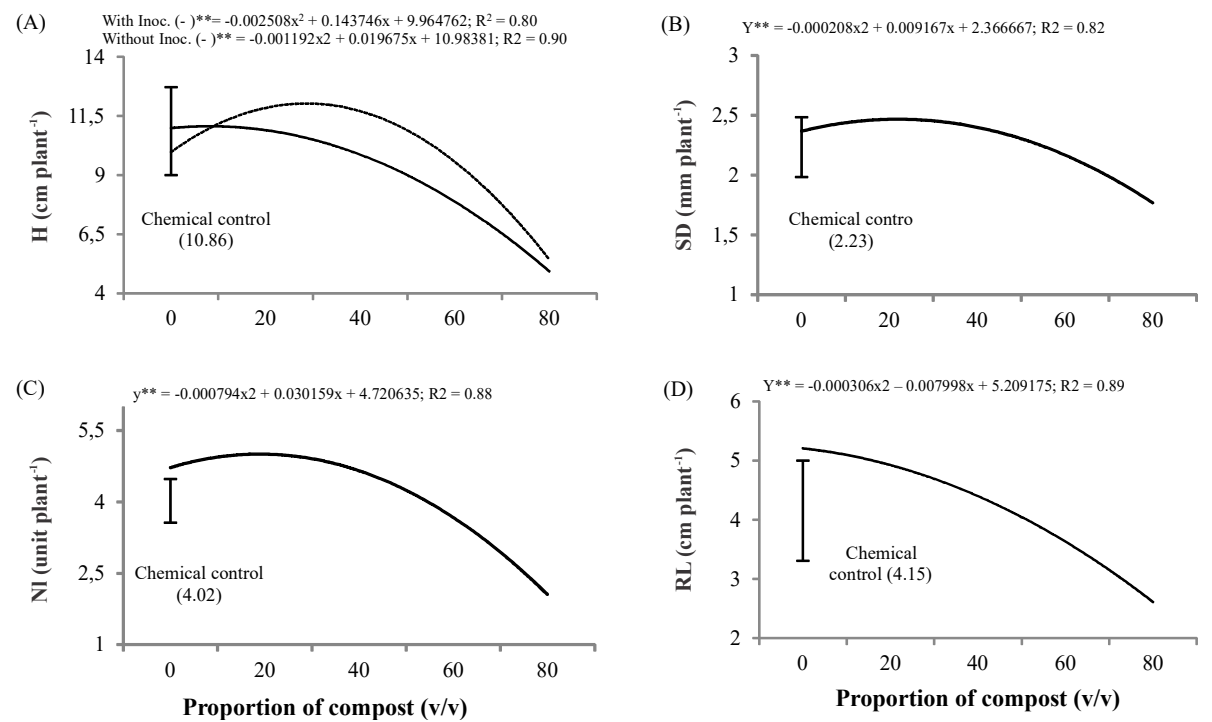

Figure 1 - Height, (H) (A); stem diameter, (SD) (B); number of leaves, (NL) (C) and radicular length, (RL) (D) of Bauhinia variegata seedlings cultivated in different proportions of organic compost made from pruned trees supplemented with cattle and goat manure, with ( $\square$ ) or without $(\square)$ inoculant and chemical fertilization, 90 days after sowing

Figura 1 -Altura, (H) (A); Diâmetro do caule, (SD) (B); Número de folhas, (NL) (C) e Comprimento radicular (RL) (D) das mudas de Bauhinia variegata cultivadas em diferentes proporções de composto orgânico oriundo da poda de árvores acrescido de esterco bovino e caprino, com (ㅁ) ou sem inoculante (口) e adubação química aos 90 dias após a semeadura.

showed a lower mean value for NL (4.02 leaves plants $\left.{ }^{-1}\right)$, when compared to the organic compost (Figure 1C).

The estimated proportion of 14:86 (organic compost:soil), resulted in a maximum RL of $5.26 \mathrm{~cm}$ plant $^{-1}$ (Figure 1D). Plants cultivated with chemical fertilization showed mean value of $4.15 \mathrm{~cm}_{\text {plant }}{ }^{-1}$, thus the use of organic compost resulted in an increase of up to $49.90 \%$ in RL of $B$. variegata seedling when compared to chemical fertilization (Figure 1D).

Concerning $\mathrm{H}$, beyond the estimated proportions of 29:71 and 9:91 (organic compost:soil), for inoculated and non-inoculated treatments, respectively, a reduction of the mean values was observed (Figure 1A). A reduction was also verified for SD, NL and RL beyond the maximum proportions estimated for each of variable (Figure 1 $\mathrm{B}, \mathrm{C}$ and D).

Evaluations of dry mass and IQD showed individual effect of the proportions of organic compost:soil and inoculation, all elucidated by a quadratic behavior. There was individual effect $(\mathrm{p}<0.01)$ of organic compost proportions with and without inoculation for the dry mass of the aerial portion (DMAP) (Table 1). The estimated proportion of 19:81 (organic compost: soil

Revista Árvore. 2019;43(1):e430104
+ inoculation) resulted in a maximum estimated mean value of $0.76 \mathrm{~g} \mathrm{plant}^{-1}$ (Figure $2 \mathrm{~A}$ ). Seedlings cultivated in substrate with chemical fertilization showed 0.60 g plant ${ }^{-1}$ (Figure 2A).

Concerning to the dry mass of roots (DMR), the estimated proportion of 35:65 (organic compost:soil + inoculation), resulted in a maximum production of $0.68 \mathrm{~g} \mathrm{plant}^{-1}$, when compared to the substrate constituted only by organic compost:soil, with 0.41 g plant $^{-1}$ (Figure $2 \mathrm{~B}$ ). Seedlings cultivated in substrate with chemical fertilization showed a lower value of 0.43 $\mathrm{cm}$ plant $^{-1}$ (Figure 2B), when compared to the substrate with organic compost:soil + inoculation, which resulted in an increase of $74.60 \%$ in DMR.

Regarding the total dry mass (TDM), there was an individual effect of the proportions with organic compost and inoculation $(p<0.05)$ and for proportions of organic compost without inoculation $(p<0.01)$ (Table 1$)$. The estimated proportion of 19:81 (organic compost:soil + inoculation), rendered a higher production, with maximum TDM of $0.97 \mathrm{~g}$ plant-1, an increment of $64.76 \%$ when compared with the substrate constituted only by organic compost:soil, with 0.70 g plant-1 (Figure 2C). Plants cultivated in a substrate with chemical 
Table 1 - Dry mass of the aerial portion (DMAP), dry mass of roots (DMR), total dry mass (TDM), Dicksosn's quality index (IQD), nitrogen content (N) of the aerial portion and $\mathrm{C} / \mathrm{N}$ ratio in Bauhinia variegata seedlings 90 days after sowing, in response to inoculation and different proportions of organic compost.

Tabela 1 - Médias de massa seca da parte aérea (DMAP), massa seca da raiz (DMR), massa seca total (TDM), indice de qualidade de Dickson (IQD), teor de nitrogênio $(N)$ da parte aérea e relação C/N de mudas de Bauhinia variegata, aos 90 dias após a semeadura, em resposta a inoculação e proporções de composto orgânico.

\begin{tabular}{ccccccc}
\hline & DMAP & DMR & TDM & IQD & C/N \\
\cline { 2 - 6 } & & $\left(\right.$ g planta $\left.^{-1}\right)$ & & \\
\hline With Inoculation & $0.64 \mathrm{a}$ & $0.45 \mathrm{a}$ & $0.78 \mathrm{a}$ & $0.31 \mathrm{a}$ & $1.84 \mathrm{~b}$ \\
Without Inoculation & $0.57 \mathrm{~b}$ & $0.41 \mathrm{~b}$ & $0.70 \mathrm{~b}$ & $0.27 \mathrm{~b}$ & $1.97 \mathrm{a}$ \\
CV\% & 20.37 & 21.62 & 20.05 & 24.94 & 7.37 \\
\hline
\end{tabular}

Means followed by the same letter within the column are not statistically different by the F test.

fertilization showed a lower value of 0.74 g plant $^{-1}$, when compared to the results obtained with organic compost:soil (Figure 2C).

As for nitrogen content ( $\mathrm{mg}$ ), an individual effect of inoculation (Table 1) and of proportions of organic compost (Figure 3A), were observed. The estimated proportion of 62:38 (organic compost:soil), resulted in the maximum nitrogen content of $2.09 \%$, with an increment of $28.10 \%$, when compared to the organic compost:soil + inoculation with $1.84 \%$ (Figure $3 \mathrm{~A}$ ).
Chemical fertilization showed a lower value, with $\mathrm{N}$ content of $1.79 \%$ (Figure $3 \mathrm{~A}$ ).

Regarding to the percentage of carbon, an interaction was observed $(p<0.05)$ between the proportions of organic compost with and without inoculation. A decreasing linear effect was verified for the treatment of organic compost with inoculation and a decreasing quadratic effect for the treatment of organic compost without inoculation (Figure 3B). The estimated proportion of 11:89 (organic compost:soil), resulted in a maximum
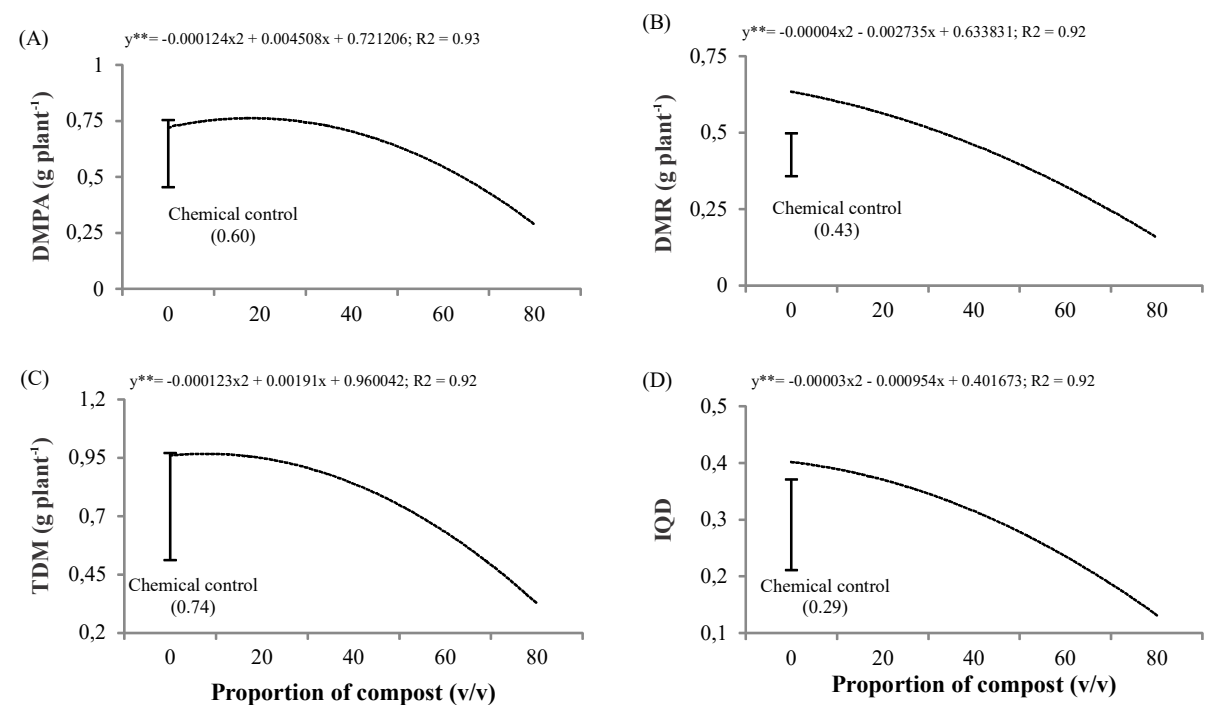

Figure 2 - Dry mass of the aerial portion (DMAP) (A); dry mass of roots (DMR) (B); total dry mass (TDM) (C) and Dicksosn's quality index (IQD) (D) from seedlings of Bauhinia variegata cultivated under different proportions of organic compost from pruned trees supplemented with cattle and goat manure and chemical fertilization, 90 days after sowing.

Figura 2-Massa seca da parte aérea (DMAP) (A); e da raiz (DMR) (B); Massa seca total (TDM) (C) éndice de qualidade de Dickson IQD (D) das mudas de Bauhinia variegata cultivadas em diferentes proporções de composto orgânico oriundo da poda de árvores acrescido de esterco bovino e caprino, com () ou sem inoculante (ם) e adubação química aos 90 dias após a semeadura. 

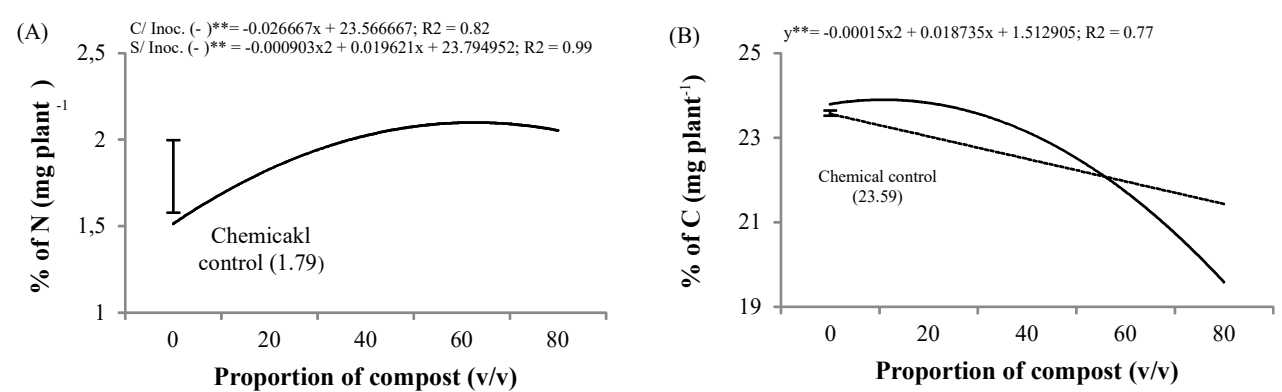

Figure 3 - Content of nitrogen (A) and content of carbon (B) of the aerial portion from Bauhinia variegata seedlings cultivated under different proportions of organic compost from pruned trees supplemented with cattle and goat manure, with $(\square)$ or without ( $\square$ ) inoculation and chemical fertilization, 90 day after sowing.

Figura 3 - Teor de nitrogênio (A) e teor de carbono (B) da parte aérea das mudas de Bauhinia variegata cultivadas em diferentes proporções de composto orgânico oriundo da poda de árvores acrescido de esterco bovino e caprino, com () ou sem inoculante (ם) e adubação química aos 90 dias após a semeadura.

carbon content of $23.90 \%$, with an increase of $17.83 \%$, when compared to the proportion of organic compost:soil + inoculation of $23.11 \%$.

Chemical fertilization rendered a carbon content value of $23.59 \%$, seedlings cultivated under organic compost were more responsive to the increment of C than chemical fertilization, although there was no statistical difference $(p>0.05)$ when compared to the substrate constituted only by soil (0:100 v:v) (Figure 3B).

With respect to the $\mathrm{C} / \mathrm{N}$ ratio, there was an individual effect of organic compost ( $<<0.01$ ), with a decreasing quadratic effect. As the addition of organic compost was increased, the $\mathrm{C} / \mathrm{N}$ ratio diminished, the proportion 80:20 (organic compost:soil), resulted in a lower C/ $\mathrm{N}$ ratio with mean value of 10.21 (Figure 4). Seedlings cultivated under substrate including chemical fertilization showed higher $\mathrm{C} / \mathrm{N}$ ratio (14.57), when compared to seedlings fertilized with organic compost (Figure 4).

\section{DISCUSION}

Literature reports that $B$. variegata is not capable of nodulation (Sprent, 2009), in agreement with the results in the present work. It was also verified that, independently form nodulation, there was a positive effect from inoculation over seedling height, dry mass of the aerial portion and roots, total dry mass, IQD and foliar contents of $\mathrm{N}$ and $\mathrm{C}$.

These effects may be attributed, probably not only to the capacity for biological fixation of $\mathrm{N}_{2}$, but also to the production of phytohormones (such as auxins, cytokinins and gibberellins) and solubilization of phosphates and exopolisaccharides by diazotrophic bacteria (Gumiere et al., 2014; Costa et al., 2016; Silva et al., 2016; Porto et al., 2016). As registered for strains of the genus Bradyrhizobium, which increased the production of Inga edulis (Porto et al., 2017), many arboreal species are responsive to inoculation, as also the normative from the Ministry of Agriculture, Livestock and Supply (Brasil, 2011) states, for approximately 23 arboreal legume species which have authorization to be inoculated in the seedling stage. Basic research work of selection or recommendation of inoculants evidences that inoculation stimulates vegetal growth of various species. Works with cowpea showed results with various strains of symbiotic diazotrophic bacteria,

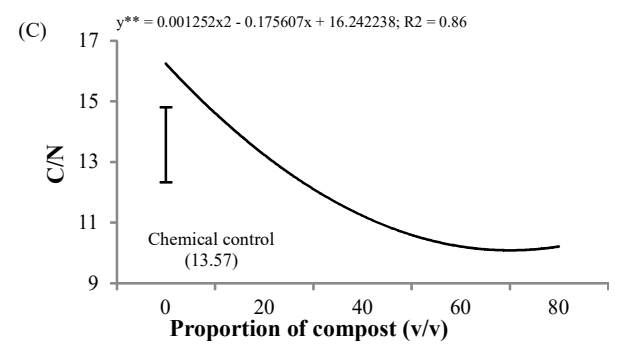

Figure 4 - Ratio of $\mathrm{C} / \mathrm{N}$ in the foliar area from Bauhinia variegata seedlings cultivated under different proportions of organic compost from pruned trees supplemented with cattle and goat manure and chemical ertilization, 90 days after sowing.

Figura 4-Relação C/N da área foliar das mudas de Bauhinia variegata cultivadas em diferentes proporções de composto orgânico oriundo da poda de árvores acrescido de esterco bovino e caprino sem inoculante (一) e adubação química aos 90 dias após a semeadura.

Revista Árvore. 2019;43(1):e430104 
established or native, producing hormones, solubilizing nutrients and increasing the biological fixation of nitrogen and productivity (Guimarães et al., 2012; Costa et al., 2016).

Although the strains used in the present work are recommended for Vigna unguiculata L. and one strain is still under selection stage (due to its potential as inoculant), it was verified a positive stimuli for initial growth in Bauhinia variegata seedlings.

Therefore, there is a possibility to test mixtures of already authorized inoculants (Brasil, 2011) in non nodulating species, which may have the potential for recover degraded areas and for urban afforestation. The easy acquisition of inoculants, once they are authorized by the legislation, may reduce the research time demanded for other vegetal species . The use of organic compost:soil in association with inoculation increased the growth in height of $B$. variegata seedlings. It is essential to mention the importance of the organic compost elaborated from pruned trees and animal manure to supply organic matter and nutrients to substrates constituted by soil. This compost represents an alternative to formulate cultivation substrates, once it shows satisfactory contents of macro and micro nutrients according to the Brazilian legislation (Brasil, 2009), defined by the classification of organic fertilizer, being precisely classified as Class A. This material shows potential to increase physical properties of the soil, such as water retention and preservation of chemical characteristics of the substrate, important issues which may influence directly on foliar and radicular growth of seedlings (Delarmelina et al., 2014; Medeiros et al., 2017).

The organic compost in association to inoculation propitiated higher growth in height for $B$. variegata seedlings, when compared to chemical fertilization. Positive effects over growth in height from organic compost used in cultivation substrates for seedlings were also verified in Gliricidia sepium seedlings (Cavalcante et al., 2016).

It was verified that seedlings of $B$. variegata cultivated in supplemented substrates, with organic compost as well as with chemical fertilization, reached SD values above $2 \mathrm{~mm}$ plant ${ }^{-1}$, as observed by Gomes et al. (1996). Seedlings of B. variegata showed higher stem diameter when cultivated in substrate constituted by soil of desertic area + cured cattle manure (1:1) (Fernandes et al., 2015). In Sesbania virgata seedlings, the substrate combining sludge and vermiculite at a proportion of $60: 40 \%$, influenced growth of stem diameter (Delarmelina et al., 2014). Seedlings with higher SD tent to be more resistant to damping-off in field conditions.

$\mathrm{Up}$ to the value of the estimated proportion of organic compost:soil, there was an increase in the number of leaves, probably by the enhancement of the chemical and physical properties of the substrates (Figure 1C). Similar behavior occurred for B. variegata when cultivated in substrates based on poultry bed (Krefta et al., 2017). There was also a higher mean value (9.76 leaves $^{-1}$ ) observed in $B$. forficata seedlings when using cow urine at a concentration of 5\% (Raulino et al., 2015). However, fertilization with organic compost reduced the number of leaves in Moringa oleifera (Medeiros et al., 2017). In B. variegata proportions higher than 20:80 (compost:soil) reduced the number of leaves.

The addition of organic compost to the soil propitiated a positive response in root length in $B$. variegata seedlings. This may be attributed to the improvement of the aeration ability and the reduction of density and water retention of the substrates, as a result of addition of the organic matter. Chemical fertilization did not influence the radicular length of $B$. variegata seedlings, when compared to organic compost. Although organic residues have lower contents of nutrients when compared to mineral fertilizers, they are constituted by a greater diversity of nutrients (Rodrigues et al., 2011).

B. variegata is responsive to the substrates formulated in the present work. Seedlings of this species, when cultivated in substrate constituted by cattle manure (1.27 g plant $\left.^{-1}\right)$ and goat manure $\left(0.55\right.$ g plant $\left.^{-1}\right)$, also exhibited positive response 90 day after sowing (Fernandes et al., 2015). Being soil fertility an important factor for the initial growth of $B$. variegata, it is important that growth substrates may provide nutrients for the photosynthesis, generating energy needed for biomass accumulation and plant development, as registered in data showed in Figures $2 \mathrm{a}, \mathrm{b}, \mathrm{c}$ and $\mathrm{d}$.

The organic compost used to prepare the substrates showed adequate contents of $\mathrm{Ca}$ and $\mathrm{P}$ to promote an increment of dry mass of seedlings, and favorable content of organic matter, in addition to adequate $\mathrm{C} /$ $\mathrm{N}$ ratio (9) and $\mathrm{pH}$ (6.4). This provides higher mineralization of the organic matter for the seedlings (Brasil, 2009). Chemical fertilization did not influence the gathering 
of dry mass by the seedlings, when compared to seedlings cultivated in substrates constituted by organic compost:soil. Another species within the same genus, B. forficata, showed increase of DMR, up to a maximum point $(100 \%)$ with mean value of $12.35 \mathrm{~g}$ with the addition of P dosages (Ramos et al., 2000).

As responsiveness of seedlings to IQD was verified, our results show that seedlings cultivated with substrates constituted of 16:84 (organic compost:soil) have better quality. Positive effect of organic compost on IQD was also observed in seedlings of $B$. variegata cultivated in substrate prepared with poultry bed (Krefta et al., 2017) and in E. contortisiliquum cultivated in substrates added with organic compost:soil at a proportion of 43:57 (Sousa et al., 2016).

In the present work we verified that addition of organic compost to the substrate granted a higher content of $\mathrm{N}$ in the aerial portion of $B$. variegata seedlings, when compared to chemical fertilization. The content of $\mathrm{N}$ in the aerial portion of the seedlings may be related with a higher radicular growth and production of biomass of $B$. variegata seedlings, impelling photosynthesis and promoting a higher initial growth (Freiberger et al., 2013). Seedlings of Enterolobium contortsiliquum (vell.) Morong, showed higher content of $\mathrm{N}\left(4.2 \mathrm{mg} \mathrm{g}^{-1}\right)$, when cultivated in substrate constituted of 48:52 (decomposed stem of moriche palm:soil), 80 days after sowing (Sousa et al., 2013).

Seedlings of $B$. variegata showed a higher content of $\mathrm{C}$ in the DMAP, due to the organic compost. Seedlings of Mimosa scabrella, also showed higher contents of $\mathrm{C}$ in the biomass with values of 44.69 and $45.33 \%$ (Dallagnol et al., 2011). The low $\mathrm{C} / \mathrm{N}$ ratio of leguminous species is related to the presence of soluble compounds, which contributes to mineralization and degradation efficiency, thus contributing to the $\mathrm{N}$ input into the soil (Ferreira et al, 2011). The analysis of the $\mathrm{C} / \mathrm{N}$ ratio shows $B$. variegata has a low content of lignin and low $\mathrm{C} / \mathrm{N}$ ratio, suggesting fast mineralization of the foliar portion and consequently being this an auspicious species to be used as green fertilizer. Carbon, as well as $\mathrm{N}$, is a component of the organic matter which results in the improvement of the metabolism and hormonal equilibrium of plants, influencing nutrients absorption and its efficiently utilization, thus contributing to the nutritional status of the plant and its biological functioning (Dallagnol et al., 2011; Freiberger et al., 2013).
In a general way, we observed that proportions above 20:80 (organic compost:soil) promoted a reduction in the majority of variables evaluated in this work. Such phenomena results from the nutritional disequilibrium, due to the high concentration of soluble salts $\left(\mathrm{B}, \mathrm{Na}^{+}\right.$, $\mathrm{Mn}^{2+}$ ) in the organic compost which may have reduced the availability of nutrients demanded in higher quantities by the plant, affecting its development. The osmotic effect form salinity affects the development of plants, once it generates nutritional disequilibrium, making water and nutrients unavailable for plant absorption (Alves et al., 2011).

The substrate prepared with organic compost from pruned trees, added with cattle and goat's manure and yellow Latosol, positively influenced the growth and nutritional status of $B$. variegata seedlings, 90 days after sowing, resulting in the production of quality seedlings in a short time period in the nursery. Although the species $B$. variegata did not show nodulation, inoculation with diazotrophic bacteria stimulated its development during the seedling stage.

\section{CONCLUSIONS}

Inoculation of diazotrophic bacteria increased growth in height, the height/stem diameter ratio, dry mass of roots and aerial portion, total dry mas and carbon contents total in Bauhinia variegata L. seedlings.

Seedlings of Bauhinia variegata L. cultivated under organic compost showed better development when compared with seedlings cultivated in soil and substrate with chemical fertilization.

The addition of organic compost from pruned trees, supplemented with cattle and goat's manure, to the yellow Latosol, increased contents of foliar nitrogen and carbon in Bauhinia variegata $\mathrm{L}$.

The substrate formulated at the proportion of 16:84 (organic compost:soil + inoculation), resulted in the highest Dickson's quality index, being therefore recommended for production of Bauhinia variegata L. seedlings.

\section{REFERENCES}

Alves FAL, Silva FSL, Silveira, JAG, Pereira, VLA. Effect of external $\mathrm{Ca}^{2+}$ in the $\mathrm{Na}^{+}$and $\mathrm{K}^{+}$content incashew exposed to salinity. Revista Brasileira de Ciências Agrárias. 2011;6(4):602-8.

Revista Árvore. 2019;43(1):e430104 
Brasil. Ministério da Agricultura, Pecuária e Abastecimento. Diário Oficial da União - Seção 1 Instrução normativa no13 de 24 de março de 2011.

Brasil. Ministério da Agricultura, Pecuária e Abastecimento. Instrução Normativa no 25, de 23 de julho de 2009. Anexo III 2009[Online].

Cavalcante ACP, Silva AG, Silva MJR, Araújo RC. Seedling production of Gliricídia with different organic substrates. Revista Agrarian.

2016;9(33):233-40.

Costa EM, Carvalho F, Nóbrega RSA, Silva JS, Moreira FMS. Bacterial strains from floodplain soils perform different plant-growth promoting processes and enhance cowpea growth. Scientia Agrícola. 2016;73(4):301-10.

Dallagnol FS, Mognon F, Sanquetta CR, Corte APD. Carbon contents of five forest species and their compartments. Floresta and Ambiente. 2011;18(4):410-46.

Delarmelina WM, Caldeira MVW, Faria JCT, Gonçalves EO, Rocha RLF. Different substrates for the production of Sesbania virgata Seedlings. Revista Floresta e Ambiente. 2014;21(2)224-33.

Dickson A, Leaf AL, Hosner JF. Quality appraisal of white spruce and white pine seedling stock in nurseries. Forest Chronicle. 1960;36:10-13.

Duarte DM, Nunes UR. Initial growth of Bauhinia forficata Link seedlings on different substrates. Cerne. 2012;18(2):327-34.

Fernandes MM, Fernandes MRM, Sousa FL. Production of seedlings of three tree species for the recovery of areas in the process of desertification. Revista Científica Eletrônica de Engenharia Florestal, v25, n1, 2015.

Fernandes RM, Nóbrega RSA, Fernandes MR, Souza WC, Lustosa Filho JF. Substrates and inoculation with Bradyrhizobium growth of tamboril (Enterolobium contortisiliquum) degraded área. Revista Agrarian. 2017;10(35):52-60.

Ferreira DF. SISVAR: A guide for its bootstrap procedures in multiple comparisons. Ciência e Agrotecnologia. 2014;38:109-12.
Ferreira EPB, Stone LF, Partell FL, Didonet AD. Productivity of common bean influenced by cover crops and soil management systems. Revista Brasileira de Engenharia Agrícola e Ambiental. 2011;15(7):695-701.

Ferreira LVM, Nóbrega RSA, Silva GC, Nóbrega JCA, Moreira FMS. Growth and nodulation of Sesbania virgata with native and introduced strains. Revista de Ciências Agrárias. 2015;58(4):327-34.,

Freiberger MB, Guerrini IA, Galetti G, Fernandes DM, Corrêa JC. Initial growth and nutrition of cedar (Cedrela fissilis Vell.) As a function of nitrogen doses. Revista Árvore.2013;37(3):385-92.

Freire JM, Jesus EC, Rouws JRC, Faria SM, Zilli JE. Effect of substrate on the growth of Mimosa bimucronata seedlings inoculated with rhizobia strains. Pesquisa Florestal Brasileira. 2017;37(90):131-8.

Gomes JM, Paiva HN, Couto L. Production of eucalyptus seedlings. Informe

Agropecuário.1996;18(185):15-22.

Guimarães AA, Jaramillob PMD, Nóbrega RSA, Florentino LA, Silva KB, Moreira FMS. Genetic and symbiotic diversity of nitrogen-fixing bacteria isolated from agricultural soils in the Western Amazon by using cowpea as the trap plant. Applied and Environmental Microbiology. 2012;78(18):6726-33.

Gumiere T, Ribeiro CM, Vasconcellos RL, Cardoso EJ. Indole-3-acetic acid producing root-associated bacteria on growth of Brazil Pine (Araucaria angustifolia) and Slash Pine (Pinus elliottii)Antonie Van Leeuwenhoek. 2014;105(4):663-9.

Krefta MS, Brun EJ, Facchi SP, Santos LM, Klein DR, Krefta SC, et al. Initial development of seedlings of Bauhinia variegata LAND Ceiba speciosa (AStHil.) Ravenna under substrates based on poultry litter. Revista Scientia Agraria Paranaesis. 2017;16(1):99-106.

Lacerda AM, Moreira FMS, Andrade MJB, Soares ALL. Effect of rhizobia strains on nodulation and productivity of cowpea. Revista Ceres. 2004;51:67-82. 
Lorenzi H. Árvores brasileiras: Manual de identificação e cultivo de plantas arbóreas nativas do Brasil. $5^{\text {a }}$. ed. Nova Odessa: Instituto Plantarum; 2008. v1.

Medeiros RLS, Cavalcante AG, Cavalcante ACP, Souza VC. Growth and quality of Moringa oleifera Lamseedlings in different proportions of organic composto. Revista IFES Ciência. 2017;3(1)204-216.

Nascimento JC, Lage LFO, Carmagos CRD, Amaral JC, Costa LM, Sousa AN, et al. Antioxidant determination activity by DPPH method and assay for total flavonoids in leaves extracts of Bauhinia variegata L. Revista Brasileira de Farmácia. 2011;92(4):327-32.

Porto DS, Farias ENC, Chaves JS, Souza BF, Medeiros RD, Zilli JE, et al. Symbiotic effectiveness of Bradyrhizobium ingae in promoting growth of Inga edulis MartSeedlings. Revista Brasileira de Ciência do Solo. 2017;41:e0160222.

Raulino WNC, Cavalcante ALG, Silva HER, Ferreira LL, Porto VCN. Seedlings behavior Bauhinia forficata in cow urine of doses function applied via leaf. Cadernos de Agroecologia. 2015;10(3)não paginado

Ramos MRC, Pinto JEPB, Furtini Neto AE, Davide AC. Influence of the application of Nitrogen, Phosphorus and Potassium on growth and mineral composition of Bauhinia forficata Link (Bauhinia forficata Link) Revista Brasileira de Plantas Medicinais. 2000;3:79-86.

Rodrigues PN, Rolim MM, Bezerra Neto E, Costa RN, Pedrosa EM, Oliveira VS. Effect of compaction and organic compost application on corn biomass and macronutrient contents in soil. Revista Brasileira de Engenharia Agrícola e Ambiental. 2011;15:788-93.

Silva FG, Santos IB, Souza AJ, Farias ARB, Diniz WPS, Kuklinsky-Sobral J, et all.

Bioprospecting and plant growth-promoting bacteria tolerant to salinity associated with Atriplex nummularia Lin saline soils. African Journal of Microbiology Research. 2016;10(31):1203-14.

Smiderle OJ, Luz FJF. Overcoming dormancy of pata-de-vaca (Bauhinia angulata Vell) seeds. Revista Agroambiente On-line, 2010.4(2):80-5.

Sousa LB, Lustosa Filho JF, Amorim SPN, Nóbrega RSA, Nóbrega JCA. Regional substrates in germination, growth, and natural nodulation of Enterolobium contortisiliquums. Revista Brasileira de Agroecologia. 2016;1(4):345-53.

Sousa WC, Nóbrega RSA, Nóbrega JCA, Brito DRS, Moreira FMS. Nitrogen sources and Mauritia flexuosa decomposed stem on nodulation and growth of Enterolobium contortsiliquum. Revista Árvore. 2013;37(5):969-79.

Sprent JI. Legume nodulation. London: John Wiley and Sons; 2009.

\section{ERRATA}

No artigo “GROWTH RESPONSE OF Bauhinia Variegata L. TO INOCULATION ANDORGANIC FERTILIZATION”, publicado no número 1, volume 43, da Revista Árvore, onde se lê:

Caliane da Silva Braulio², Rafaela Simão Abrahão Nóbrega ${ }^{3 *}$, Flávia Melo Moreira ${ }^{4}$, Ângela Santos de Jesus Cavalcante dos Anjos ${ }^{5}$, Janildes de Jesus da Silva ${ }^{6}$ and Juan Manuel Anda Rocabado ${ }^{2}$

L eia-s e:

Caliane da Silva Braulio ${ }^{2 *}$, Rafaela Simão Abrahão Nóbrega ${ }^{3}$, Flávia Melo Moreira ${ }^{4}$, Ângela Santos de Jesus Cavalcante dos Anjos ${ }^{5}$, Janildes de Jesus da Silva ${ }^{6}$ and Juan Manuel Anda Rocabado ${ }^{2}$

onde se lê:

NÓBREGA RSA ET AL.

L eia-s e:

BRAULIO CS ET AL. 